\title{
EFFECT OF GIBBERELLIC ACID AND TEMPERATURE ON GERMINATION OF Vitex montevidensis Cham.
}

\author{
Marlene de Matos Malavasi ${ }^{1}$, Glaucia Bravo Dias², Ubirajara Contro Malavasi ${ }^{3}$
}

(received: November 30, 2009; accepted: February 25, 2011)

\begin{abstract}
This work aims to evaluate treatments that may help improve speed and uniformity of germination in fruit tree species tarumã. Data were obtained from pyrenes (stones) of ripe fruits which in turn were picked from adult trees in the municipality of Vera Cruz do Oeste-PR. Treatments consisted of applying GA solutions at various concentrations (zero, $50 \mathrm{mg} \mathrm{L}_{3}^{-1}, 100 \mathrm{mg} \mathrm{L}^{-1}$ or $\left.200 \mathrm{mg} \mathrm{L}^{-1}\right)$ to pyrenes via immersion for 47 hours, and thermoperiods of alternate $20^{\circ} \mathrm{C}$ and $30^{\circ} \mathrm{C}\left(8\right.$ hours at $20^{\circ} \mathrm{C}$ in light conditions, and 16 hours at $30^{\circ} \mathrm{C}$ in dark conditions) and constant $30^{\circ} \mathrm{C}$ with the same photoperiod. The combination of alternate temperatures of $20^{\circ} \mathrm{C}$ and $30^{\circ} \mathrm{C}$ with a $200 \mathrm{mg} \mathrm{L}^{-1} \mathrm{GA}_{3}$ solution resulted in an increase both in germination percentage, from $19.2 \%$ to $56.2 \%$, and in the germination speed index, from 0.19 to 3.12 , with resulting normal, uniform seedlings.
\end{abstract}

Key words: Pyrenes, imbibition curve, tarumã, thermoperiod.

\section{EFEITO DO ÁCIDO GIBERÉLICO E DA TEMPERATURA NA GERMINAÇÃO DE Vitex montevidensis Cham.}

RESUMO: Objetivou-se, com este trabalho, avaliar tratamentos que proporcionem maior rapidez e uniformidade na germinação de tarumã. Os dados foram obtidos de pirênios extraídos de frutos maduros coletados em árvores adultas no município de Vera Cruz do Oeste, PR. Nos tratamentos,utilizaram-se soluções com concentrações de GA (zero, 50, 100, ou $200 \mathrm{mg} \mathrm{L}^{-1}$ ) aplicadas aos pirênios por imersão, durante 47 horas, e termoperíodos de 20 e $30{ }^{\circ} \mathrm{C}$ alternados $\left(8\right.$ horas a $20^{\circ} \mathrm{C}$ no claro, e 16 horas a $30{ }^{\circ} \mathrm{C}$ no escuro) e $30^{\circ} \mathrm{C}$ constante com o mesmo fotoperíodo. A combinação de temperaturas alternadas de 20 e $30^{\circ} \mathrm{C}$ com solução de $200 \mathrm{mg} \mathrm{L}^{-1}$ de $\mathrm{GA}_{3}$ resultou em um aumento na porcentagem germinação de 19,2\% para 56,2 \%, e do índice de velocidade de germinação de 0,19 para 3,12 com a consequente uniformidade na obtenção de plântulas normais.

Palavras-chave: Pirênios, curva de embebição, tarumã, termoperíodo.

\section{INTRODUCTION}

Literature has demonstrated that endogenous compounds that promote and inhibit growth are directly involved in the germination process (ARAGÃO et al., 2003; PASSOS et al., 2004; SCALON et al., 2004). These substances may act alone or in combination with others, not only during the germination process but also in postgermination events such as energy reserve mobilization. Studies on the effect of gibberellic acid on seed germination of nonfruit woody species are limited to Guarea guidonea (CASTRO et al., 1999), Cassia excelsa (JÉLLER; PEREZ, 1999), Jacaranda cuspidifolia (SCALON et al., 2006), Senna spectabilis (JÉLLER; PEREZ, 2001), and Talisia esculenta (VIEIRA; GUSMÃO, 2006b).

Seed germination may demand gibberellins for one of the following stages: activation of the embryo's vegetative growth, weakening of the endosperm layer that involves the embryo and obstructs its growth, and mobilization of the energy reserves of the endosperm (TAIZ; ZIGER, 2008). According to these authors, applying gibberellins $\left(\mathrm{GA}_{3}\right)$ also stimulates the production of various hydrolases, including $\alpha$-amylase, by aleurone layer cells of germinating cereal grains. During germination and initial growth of seedlings, endosperm reserves, particularly starch and protein, are hydrolized by various hydrolytic enzymes, and the solubilized sugars, aminoacids and other products are transported to the developing embryo. Gibberellin can be a limiting factor to $\alpha$-amylase production during seed germination (CASTRO et al., 2004).

Gibberellin induces seed germination and promotes hypocotyl and stem elongation (PENG; HARBERD, 2000; RICHARDS et al., 2001). The use of growth regulators

\footnotetext{
${ }^{1}$ Agronomic Engineer, Professor Ph.D. in. Forest Sciences - Centro de Ciências Agrárias - Universidade Estadual do Oeste do Paraná/Unioeste Rua Pernambuco 1777 - 85960-000 - Marechal Candido Rondon, PR, Brasil - marlenemalavasi@yahoo.com.br

${ }^{2}$ Agronomic Engineer, M.Sc. in Plant Production - Prefeitura Municipal de Vera Cruz - Rua Duque de Caxias, 2022 - 85845-000 - Vera Cruz do Oeste, PR, Brasil-glauciabdias@yahoo.com.br

${ }^{3}$ Forest Engineer, Professor Ph.D. in Forest Sciences - Centro de Ciências Agrárias - Universidade Estadual do Oeste do Paraná/Unioeste Rua Pernambuco 1777 - 85960-000 - Marechal Candido Rondon, PR, Brasil - biramalavasi@yahoo.com.br
} 
in seed germination is not as well disseminated with forest species as it is with fruit-bearing, vegetable, and medicinal species. While working with seeds of Passiflora alata, Rosseto et al. (2000) observed that using $\mathrm{GA}_{3}$ at a concentration of $300 \mathrm{mg} \mathrm{L}^{-1}$ was more effective in promoting germination. Still with Passiflora alata, Ferreira (1998) observed that $\mathrm{GA}_{3}$ at $100 \mathrm{mg} \mathrm{L}^{-1}$ promoted better germination, while with Passiflora nitida Passos et al. (2004) reported that for in vitro germination the most suitable gibberellic acid concentration was $1000 \mathrm{mg} \mathrm{L}^{-1}$, with or without luminosity. Botelho and Perez (2001) reported significant effects on the germination percentage and speed with seeds of Peltophorum dubium Spreng (Taubert). With seeds of Jatropha elliptica, Añez et al. (2006) found higher germination percentages in treatments using gibberellic acid at concentrations of 300 to $500 \mathrm{ppm}$. In contrast, Vieira and Gusmão (2006a) argued that GA failed to stimulate germination in a study with seeds of Genipa americana.

Studying Caryocar brasiliense, Souza and Salviano (2002) recommended using $1000 \mathrm{mg}$ of $\mathrm{GA}_{3}$ to two liters of water in order to increase germination and improve seedling growth. With the same species, Pereira et al. (2004) reported that, from 250 ppm of $\mathrm{GA}_{3}$ onward, seed germination increased significantly. Similarly, Fuentes Fiallo et al. (1996) reported an increase in germination of oregano seeds (Ocimum gratissimum) with exogenous application of gibberellic acid starting at $250 \mathrm{ppm}$ and as recommended for economic reasons, whereas applying the same substance for germination of the same species partially reverted light requirements (FACTOR et al., 2008).

In germination, response to temperature is dependent on species, variety, originating location and storage period. Some species require alternate temperatures to germinate while others are indifferent to that stimulus (CETNARSKI FILHO; NOGUEIRA, 2005).

Vitex montevidensis occurs in Atlantic Forest environment, from Bahia down to Rio Grande do Sul, and also in Florestas de Pinhais, Cerradão and Florestas Semideciduas of Paraná River basin. Fruits are consumed fresh or used for making candies and liqueur. The species can be used in conservation-oriented reforestation practices, providing both fruits to feed the local fauna and good quality wood (CARDOSO, 2004). However, the germination rate of tarumã seeds is less than $10 \%$ (LORENZI, 2000) and seed emergence is difficult where no-till planting is involved (CARRASCO et al., 2007).
The objective of this work is to evaluate the effects of $\mathrm{GA}_{3}$ application and temperature on the germination of tarumã seeds.

\section{MATERIAL AND METHODS}

Reproductive structures of tarumã were collected in March 2005 from adult plants located in the municipality of

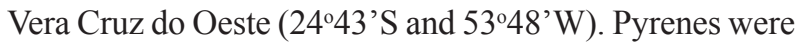
manually extracted using a surgical knife and choosing ripe fruits whose epicarp was color $1 \mathrm{~N}$ according to Munsell color chart (MUNSELL, 1976). Pyrenes were subjected to treatment immediately after being extracted.

Variables being measured included germination percentage in sterilized sand arranged in plastic trays $(40 \times 25 \times 8 \mathrm{~cm})$ and germination speed index (MAGUIRE, 1962), in four replicates of 25 pyrenes each.

The quantification of gibberellic acid $\left(\mathrm{GA}_{3}\right)$ and temperature effects on germination used a completely randomized design in a $4 \times 2$ factorial consisting of four $\mathrm{GA}_{3}$ concentrations and two thermoperiods. $\mathrm{GA}_{3}$ concentrations being tested included zero, $50 \mathrm{mg} \mathrm{L}^{-1}, 100 \mathrm{mg} \mathrm{L}^{-1}$ or $200 \mathrm{mg} \mathrm{L}^{-1}$, applied to pyrenes via immersion for 47 hours, according to preliminary data. Thermoperiods using BOD chambers (Fanen $\AA$, 347G model) consisted of alternate temperatures of $20^{\circ} \mathrm{C}$ and $30^{\circ} \mathrm{C}$ and constant $30^{\circ} \mathrm{C}$, both with 8 hours of light being provided by daylight fluorescent lamps (4x20 W) according to procedures suggested by Brasil (1992).

Different $\mathrm{GA}_{3}$ concentrations were applied to the solutions containing pyrenes in $500 \mathrm{~mL}$ of distilled water, in beaker glassware with a capacity of $1 \mathrm{~L}$, which were subjected to artificial air circulation using an aquarium pump (1.5 $\mathrm{L} \mathrm{min}^{-1}$ pressure, $\left.0.01 \mathrm{Mpa}\right)$ and water volume maintenance so as to prevent oxygen shortage in the solutions.

For the purpose of statistical analysis, data on germination percentage were transformed into arcsin $\sqrt{x} / 100$ and germination speed index into $x+0.5$ (SANTANA; RANAL, 2004). Results were subjected to analysis of variance and, when a statistical difference was found, means were compared using the Tukey test at the $5 \%$ probability level.

\section{RESULTS AND DISCUSSION}

Analyses of variance of germination percentage and germination speed index (IVG) data resulted in significant interaction $(\mathrm{P}<0.05)$ for the effects of applying $\mathrm{GA}_{3}$ and temperature on the germination process (Table 1). 
Table 1 - Germination percentage and germination speed index as a function of thermoperiod and GA 3 concentration.

Tabela 1 - Germinação e índice de velocidade de germinação em função do termoperíodo e da concentração de GA ${ }_{3}$.

\begin{tabular}{lccccc}
\hline \multirow{2}{*}{ Thermoperiod } & & \multicolumn{4}{c}{ Concentration } \\
\cline { 3 - 6 } & & $0 \mathrm{mg} \mathrm{L}^{-1}$ & $5 \mathrm{mg} \mathrm{L}^{-1}$ & $100 \mathrm{mgL}^{-1}$ & $200 \mathrm{mgL}^{-1}$ \\
\hline \multirow{2}{*}{ Germination (\%) } & $20-30{ }^{\circ} \mathrm{C}$ & $19.2 \mathrm{Ca}^{*}$ & $39.2 \mathrm{Ba}$ & $43.3 \mathrm{Ba}$ & $56.2 \mathrm{Aa}$ \\
& $30{ }^{\circ} \mathrm{C}$ & $16.2 \mathrm{Ca}$ & $25.0 \mathrm{Bb}$ & $46.1 \mathrm{Aa}$ & $51.4 \mathrm{Ab}$ \\
\hline \multirow{2}{*}{ Germination Speed Index (IVG) } & $20-30{ }^{\circ} \mathrm{C}$ & $0.19 \mathrm{Ca}$ & $1.05 \mathrm{Ba}$ & $1.62 \mathrm{Ba}$ & $3.12 \mathrm{Aa}$ \\
& $30{ }^{\circ} \mathrm{C}$ & $0.18 \mathrm{Ba}$ & $0.59 \mathrm{Ba}$ & $2.16 \mathrm{Aa}$ & $2.44 \mathrm{Ab}$ \\
\hline
\end{tabular}

*Means followed by the same lowercase letter in a column and uppercase letter in a line do not differ by the Tukey test $(\alpha=0.05)$.

Results of growth regulator and temperature effects indicate that the use of $\mathrm{GA}_{3}$ promoted an average germination increase in tarumã seeds from $17.7 \%$ (control) to more than $50 \%$ in treatments using $200 \mathrm{mg} \mathrm{L}^{-1}$ with any of the thermoperiods. The combination of alternate temperatures of $20^{\circ} \mathrm{C}$ and $30^{\circ} \mathrm{C}$ and a $200 \mathrm{mg} \mathrm{L}^{-1} \mathrm{GA}_{3}$ solution resulted in the highest germination percentage. When using a constant $30^{\circ} \mathrm{C}$ thermoperiod, higher germination values were observed for $\mathrm{GA}_{3}$ concentrations of $100 \mathrm{mg} \mathrm{L}^{-1}$ and $200 \mathrm{mg} \mathrm{L}^{-1}$, which did not differ statistically.

Typically, initial species in secondary succession require temperature alternation in order to germinate (BRANCALION et al., 2010). The experimental results corroborate results reported by Santos and Aguiar (2005) with seeds of tropical shrub branquilho (Sebastiania commersoniana Bailon) using alternate temperatures of $20^{\circ} \mathrm{C}$ and $30^{\circ} \mathrm{C}$, and also results found by Lopes et al. (2002) with seeds of calabura (Muntingia calabura L.), and Medeiros Filho et al. (2002) with seeds of Operculina macrocarpa (L.) Farwel and Operculina alata (Ham.) Urban.

In a study with seeds of tarumã-branco (Citharexylum myrianthum Cham.), Zanon et al. (1997) reported that seed germination values at $20^{\circ} \mathrm{C}$ were statistically lower than germination values found at a constant temperature of $25^{\circ} \mathrm{C}$ or $30^{\circ} \mathrm{C}$. However, these authors also reported that a temperature of $30^{\circ} \mathrm{C}$ caused damage to seedling cotyledons and hypocotyls when vermiculite substrate was being used.

A higher germination speed index (IVG) was obtained from observations resulting from the combination of alternate $20^{\circ} \mathrm{C}$ and $30^{\circ} \mathrm{C}$ temperatures with $200 \mathrm{mg} \mathrm{L}^{-1}$ of $\mathrm{GA}_{3}$, which did not significantly differ $(\mathrm{P}<0.05)$ from the combination between constant $30^{\circ} \mathrm{C}$ temperature and $100 \mathrm{mg} \mathrm{L}^{-1}$ of GA${ }_{3}$. Results found for the germination speed index are similar to results found for germination percentage.
These results are similar to those found by Agustin and Alviter (1996) with cherimoya seeds (Annona cherimola Mill.), who reported fast seed germination using gibberellic acid solutions of $150 \mathrm{mg} \mathrm{L}^{-1}$ to $200 \mathrm{mg} \mathrm{L}^{-1}$ for a period of twelve hours. Similarly, Ferreira et al. (2002) observed with seeds of sugar apple (Anona squamosa L.) that the highest concentration being tested $\left(200 \mathrm{mg} \mathrm{L}^{-1}\right)$ provided the best germination results. Still on the subject of gibberellic acid for seed germination, other authors obtained better germination results under conditions similar to those described in this work (AÑEZ et al., 2006; FERREIRA, 1996; FUENTES FIALLO et al., 1996; GARCIA et al., 2006; ROSSETO et al., 2000).

Experimental results lead to the conclusion that improved germination percentage and germination speed index can be obtained with tarumã seeds if using alternate temperatures of $20^{\circ} \mathrm{C}$ and $30^{\circ} \mathrm{C}$ with $200 \mathrm{mg} \mathrm{L}^{-1}$ of $\mathrm{GA}_{3}$ or a constant temperature of $30^{\circ} \mathrm{C}$ with $100 \mathrm{mg} \mathrm{L}^{-1}$ or $200 \mathrm{mg} \mathrm{L}^{-1}$ of $\mathrm{GA}_{3}$.

\section{REFERENCES}

AGUSTIN, A. J.; ALVITER, R. A. El cultivo de la Chirimoya (Annona cherimola MILL) en el Estado de Michoacán. México: Universidad Autonoma Chapingo, 1996. 62 p.

AÑEZ, L. M. M.; COELHO, M. F. B.; ALBUQUERQUE, M. C. de F. E.; DOMBROSKI, J. L. D. Efeito do ácido giberélico na germinação de sementes de Jatropha elliptica M. ARG. In: ENCONTRO ANUAL DE INICIAÇÃO CIENTÍFICA, 8., 2006, Cuiabá. Anais... Cuiabá: UFMT, 2006. p. 1.

ARAGÃO, C. A.; DANTAS, B. F.; ALVES, E.; CATANEO, A. C.; CAVARIANI, C.; NAKAGAWA, J. Atividades amilolítica e qualidade fisiológica de sementes armazenadas de milho super doce tratadas com ácido giberélico. Revista Brasileira de Sementes, Brasília, v. 25, n. 1, p. 43-48, 2003. 
BOTELHO, B. A.; PEREZ, S. C. J. G. A. Estresse hídrico e reguladores de crescimento na germinação de sementes de canafístula. Scientia Agricola, Piracicaba, v. 58, n. 1, p. 4349, 2001.

BRANCALION, P. H. S.; NOVEMBRE, A. D. L. C.; RODRIGUES, R. R. Temperatura ótima de germinação de sementes de espécies arbóreas brasileiras. Revista Brasileira de Sementes, Brasília, v. 32, n. 4, p. 15-21, 2010.

BRASIL. Ministério da Agricultura. Regra para análise de sementes. 2. ed. Brasília, 1992. 365 p.

CARDOSO, F. Árvores de Curitiba. Curitiba: Ed. do Autor, 2004. $96 \mathrm{p}$.

CARRASCO, P. L.; OLIVEIRA, C. C. C.; CAVALHEIRO, A. L.; TOREZAN, J. M. D. Semeadura direta de espécies nativas para o enriquecimento de áreas em restauração. In: CONGRESSO DE ECOLOGIA DO BRASIL, 8., 2007, Caxambu. Anais... Caxambu, 2007. Disponível em: $<$ http:// www.seb-ecologia.org.br/viiiceb/pdf/1818.pdf $>$. Acesso em: 19 ago. 2008.

CASTRO, E. M. et al. Influência do ácido giberélico e do nitrato de potássio na germinação de Guarea guidonea (L.) Sleumer. Revista Árvore, Viçosa, v. 23, n. 2, p. 255-258, 1999.

CASTRO, R. D.; BRADFORD, K. J.; HILHORST, H. W. M. Embebição e reativação do metabolismo. In: FERREIRA, A. G.; BORGHETTI, F. (Orgs.). Germinação do básico ao aplicado. Porto Alegre: Artmed, 2004. p. 149-162.

CETNARSKI FILHO, R.; NOGUEIRA, A. C. Influência da temperatura na germinação de diásporos de Ocotea odorifera (Vellozo) Rohwer (CANELA-SASSAFRÁS). Ciência

Florestal, Santa Maria, v. 15, n. 2, p. 191-198, 2005.

FACTOR, T. L.; PURQUERIO, L. F. V.; LIMA JÚNIOR, S.; ARAÚJO, J. A. C.; CURI, E. L.; TIVELLI, S. W. Efeito da temperatura, da luz e do ácido giberélico na germinação em sementes de Ocimum gratissimum L. Horticultura Brasileira, Brasília, v. 26, n. 2, p. 5314-5318, 2008. Suplemento.

FERREIRA, G. Estudo de embebição e efeito de fitoreguladores na germinação de sementes de Passifloráceas. 1998. 146 p. Tese (Doutorado) - Universidade Estadual Paulista, Botucatu, 1998.

Cerne, Lavras, v. 17, n. 2, p. 203-207, abr./jun. 2011
FERREIRA, G.; ERIG, P. R.; MORO, E. Uso de ácido giberélico em sementes de fruta-do-conde (Anona squamosa L.) visando à produção de mudas em diferentes embalagens. Revista Brasileira de Fruticultura, Jaboticabal, v. 24, n. 1, p. 178-182, 2002.

FERREIRA, S. A. N. Maturação fisiológica de sementes de pupunha (Bractris gasipaes Kunth). Manaus: INPA; UA, 1996.

FUENTES FIALLO, V. R.; MEDINA, R.; NARCISO, N.; RODRÍGUEZ FERRADÁ, C. Acerca de la propagación de Ocimum gratissimum L. Revista Cubana de Plantas Medicinales, v. 1, n. 1, 1996. Disponível em: <scielo. sld.cu/scielo.php?script=sci_arttext\&pid=S102847961996000100001\&lng=es\&nrm=isso > . Acesso em: 19 ago. 2010.

GARCIA, A. S.; BRANQUINHO, E. G. A.; MENUCHI, A. C. T. P.; ERLACHER, K. C.; DOMINGUES, M. C. S. Efeito de reguladores vegetais na germinação e desenvolvimento da semente Strelitzia reginae. Thesis, v. 5, p. 161-176, 2006.

JÉLLER, H.; PEREZ, S. C. J. G. A. A. Dormência e temperatura em sementes de Cassia excelsa. Revista Brasileira de Sementes, Brasília, v. 21, n. 1, p. 41-45, 1999.

JÉLLER, H.; PEREZ, S. C. J. G. A. A. Efeitos dos estresses hídrico e salino e da ação de giberelina em sementes de Senna spectabilis. Ciência Florestal, Santa Maria, v. 11, n. 1, p. 93104, 2001.

LOPES, J. C.; PEREIRA, M. D.; MARTINS FILHO, S. Germinação de sementes de calabura (Muntingia calabura L.). Revista Brasileira de Sementes, Brasília, v. 24, n. 1, p. 59-66, 2002.

LORENZI, H. Árvores brasileiras: manual de identificação e cultivo de plantas arbóreas nativas do Brasil. 4. ed. Nova Odessa: Plantarum, 2000. v. 1, 368 p.

MAGUIRE, J. D. Speeds of germination-aid selection emergence and vigor. Crop Science, Madison, v. 2, p. 176177, 1962.

MEDEIROS FILHO, S.; FRANÇA, E. A.; INNECCO, R. Germinação de sementes de Operculina alata (Ham.) Urban. Revista Brasileira de Sementes, Brasília, v. 24, n. 2, p. 102107, 2002. 
MUNSELL, A. H. Munsell color charts for plants tissues. Maryland: Macbeth Division of kollmorgen instruments corporation, 1976. v. 2.

PASSOS, I. R. S.; MATOS, G. V. C.; MELETTI, L. M. M.; SCOTT, M. D. S.; BERNACCI, L. C.; VIEIRA, M. A. R. Utilização do ácido giberélico para a quebra de dormência de sementes de Passiflora nítida Kunth germinadas in vitro. Revista Brasileira de Fruticultura, Jaboticabal, v. 26, n. 2, p. 380-381, 2004.

PENG, J.; HARBERD, N. P. The role of GA-mediated signalling in the control of seed germination. Current Opinion in Plant Biology, Amsterdam, v. 5, p. 376-381, 2000.

PEREIRA, E. G.; VIEIRA, F. A.; LOPES, P. S. N. Uso do ácido giberélico na superação da dormência de sementes de pequizeiro (Caryocar brasiliense Camb.). In: CONGRESSO NACIONAL DE BOTÂNICA, 55.; ENCONTRO REGIONAL DE BOTÂNICOS DE MG, BA E ES, 26., 2004, Viçosa, MG. Anais... Viçosa, MG: UFV, 2004.

ROSSETO, C. A. V.; CONEGLIAN, R. C.; NAKAGAWA, J.; SHIMIZU, M. K.; MARIN, V. A. Germinação de sementes de maracujá-doce (Passiflora alata Dryand) em função de tratamento pré-germinativo. Revista Brasileira de Sementes, Brasília, v. 22, n. 1, p. 247-252, 2000.

RICHARDS, D. E.; KING, K. E.; AIT-ALI, T.; HARBERD, N. P. How gibberellin regulates plant growth and development: a molecular genetic analysis of gibberellin signaling. Annual Review of Plant Physiology and Plant Molecular Biology, Palo Alto, v. 52, p. 67-88, 2001.

SANTANA, D. G.; RANAL, M. A. Análise da germinação: um enfoque estatístico. Brasília: UnB, 2004. 248 p.

SANTOS, S. R. G.; AGUIAR, I. B. Efeito da temperatura na germinação de sementes de Sebastiana commersoniana
(Baillon) Smith \& Downs separadas pela coloração do tegumento. Scientia Forestalis, Curitiba, v. 69, p. 77-83, 2005.

SCALON, S. de P. Q.; MUSSURY, R. M.; FRANCELINO, C. S. F.; FLORENCIO, D. K. A. Armazenamento e tratamentos pré-germinativos em sementes de Jacarandá (Jacaranda cuspidifolia Mart.). Revista Árvore, Viçosa, v. 30, n. 2, p. 179-185, 2006.

SCALON, S. de P. Q.; SCALON FILHO, H.; RIGONI, M. R. Armazenamento e germinação de sementes de uvaia eugenia uvalha Cambess. Ciência e Agrotecnologia, Lavras, v. 28, n. 6, p. 1228-1234, 2004.

SOUZA, I.; SALVIANO, A. Cultura de Pequi (Caryocar brasiliense). Belo Horizonte: Emater, 2002. Disponível em: <www.emater.mg.gov.br/servicoseprodutos/livraria/ fruticultura $>$. Acesso em: 19 ago. 2010.

TAIZ, L.; ZEIGER, E. Fisiologia vegetal. Porto Alegre: Artmed, 2008. 820 p.

VIEIRA, F. A.; GUSMÃO, E. Efeitos de giberelinas, fungicidas e do armazenamento na germinação de sementes de Genipa americana L. (Rubiaceae). Cerne, Lavras, v. 12, n. 2, p. 137-144, 2006a.

VIEIRA, F. A.; GUSMÃO, E. Uso de giberelinas na emergência de plântulas de Talisia esculenta (A. St.-Hil.) Radlk. Revista Científica Eletrônica de Engenharia Florestal, n. 8, ago. 2006b. Disponível em: <http://www. revista.inf.br/florestal08/pages/revista.htm>. Acesso em: 19 ago. 2010 .

ZANON, A.; CARPANEZZI, A. A.; FOWLER, J. A. P. Germinação em laboratório e armazenamento de sementes de tarumã - branco (Citharexylum myrianthum CHAM.). Boletim de Pesquisa Florestal, Piracicaba, n. 35, p. 75-82, 1997. 